\title{
Study on Carcass Contaminating Escherichia coli in Apparently Healthy Slaughtered Cattle in Haramaya University Slaughter House with Special Emphasis on Escherichia coli O157:H7, Ethiopia

\author{
Melaku Taye ${ }^{1}$, Tamiru Berhanu${ }^{1}$, Yenehiwot Berhanu², Firaol Tamiru ${ }^{3 *}$ and Dechassa Terefe ${ }^{2}$
}

${ }^{1}$ Faculty of Veterinary Medicine, University of Gondar, Ethiopia

${ }^{2}$ College of Veterinary Medicine, Haramaya University, Ethiopia

${ }^{3}$ College of Agriculture and Veterinary Science, Ambo University, Ethiopia

\begin{abstract}
A cross sectional study was conducted from October 2010 to March 2011, on apparently healthy slaughtered cattle in Haramaya University Slaughter House to determine prevalence of Escherichia coli, with special emphasis on Escherichia coli $\mathrm{O} 157: \mathrm{H} 7$, and its antimicrobial susceptibility pattern. Carcass swab samples were collected and pre-enriched in buffered peptone water and plated on MacConkey agar plate. Presumptive colonies were confirmed by biochemical tests. Further identification of Escherichia coli $\mathrm{O} 157: \mathrm{H} 7$ was done by plating the isolated bacteria on Sorbitol MacConkey agar; and then colorless colonies were subjected to Escherichia coli 0157:H7 Latex agglutination test. From a total of 113 samples collected, Escherichia coli was isolated from $35(30.97 \%)$ and out of these, $3(2.65 \%)$ were found to be Escherichia coli $\mathrm{O} 157: \mathrm{H} 7$. The difference in prevalence was not statistically significant $(P>0.05)$ between local and cross breeds $\left(X^{2}=0.11, \mathrm{df}=4\right)$, among age group of animals $\left(X^{2}=2.56, \mathrm{df}=1\right)$ and origin of animals $\left(x^{2}=2.56, d f=2\right)$. The isolated bacteria were subjected to antimicrobial susceptibility testing and the majority were found to be susceptible to Chloramphenicol $(30 \mu \mathrm{g})$, Kanamycin $(30 \mu \mathrm{g})$, Spectinomycin $(\mathrm{SH}$, $100 \mu \mathrm{g}$ ). The presence of $E$. coli $\mathrm{O} 157: \mathrm{H} 7$ in raw meats reaching to consumers indicated possible risks of infection to people through the consumption of raw (undercooked) meat and cross contamination of other food products. Therefore, control measures at all stages of food chain was recommended.
\end{abstract}

Keywords: Antimicrobial susceptibility test; Cattle; Escherichia coli; Haramaya University slaughter house; Prevalence

\section{Introduction}

Escherichia coli (E. coli) are normal inhabitants of the gastrointestinal tract (lower ileum and large intestine) of animals and human beings $[1,2,3]$. Some serotypes are closely correlated with certain clinical syndromes [4]. Infection with E. coli $\mathrm{O} 157: \mathrm{H} 7$ is a major food borne and zoonotic pathogen responsible for hemorrhagic colitis and hemolytic uremic syndromes in humans. Transmission to human occurs through consumption of undercooked meat, unpasteurized dairy products, and vegetables or water contaminated by feces of carrier animals [1]. Outbreaks of E. coli $\mathrm{O} 157$ have been reported in different parts of the world and antibiotic use is controversial because of the potential to increase production and secretion of Shiga toxins. Increase in antibiotic resistance has been noted over the last 20 years [5]. Differentiation of pathogenic strains from the normal flora depends on the identification of virulence characteristics [4].

In Ethiopia, there were studies conducted by few researchers $[5,6]$ to determine the occurrence and proportion of E. coli O157:H7 in faeces, skin swabs and carcasses of sheep, goat and cattle in Debre Zeit and Modjo town. Even though little is known about the prevalence and antimicrobial susceptibility pattern of this bacterium in Ethiopia either in humans or animal population or foods, there is no information in eastern Ethiopia generally and in Haramaya University and its surrounding specifically, where large populations of cattle are reared for slaughter. Therefore, the main objectives of this study were to assess prevalence of carcass contamination with $E$. coli and determine the antimicrobial susceptibility pattern of isolates from the apparently healthy slaughtered cattle in Haramaya University slaughter house.

\section{Materials and Methods}

\section{Study area and population}

The study was conducted in Haramaya University slaughter house from October 2010 to March 2011. Haramaya University is located at an altitude of 1980 meters above sea level between latitude $9^{\circ} 26^{\prime \prime} \mathrm{N}$ and longitude $42^{\circ} 3$ " $\mathrm{E}$. The mean annual rainfall is $870 \mathrm{~mm}$ with a range of $560-1260 \mathrm{~mm}$, and the mean maximum and minimum temperatures are $23.4^{\circ} \mathrm{C}$ and $8.25^{\circ} \mathrm{C}$, respectively [7]. Both local and cross breeds cattle are reared in and around the study area for meat production mostly. Cattle brought from Chalanko, Kulubi, Water, Kersa and Haramaya, and slaughtered in Haramaya University slaughter house were the study population. Since only animals above one year are brought to the slaughter house, different age groups of above one year and both breeds were included in study.

\section{Study protocol}

A cross-sectional study was conducted on all animals slaughtered during regular visit (every week) of the slaughter house. Breed, age and origin were considered as risk factors. The age of individual study animal was determined according to De-Lahunta and Habel [8]. Carcass swab samples were collected from all apparently healthy slaughtered cattle using sterile cotton swab dipped in hydrated Buffered Peptone Water (BPW) according to the method described

*Corresponding author: Firaol Tamiru, College of Agriculture and Veterinary Science, Ambo University, P. O. Box 19, Ambo University, Ethiopia, E-mail: tfiraol@gmail.com

Received January 06, 2013; Accepted February 02, 2013; Published February 04,2013

Citation: Taye M, Berhanu T, Berhanu Y, Tamiru F, Terefe D (2013) Study on Carcass Contaminating Escherichia coli in Apparently Healthy Slaughtered Cattle in Haramaya University Slaughter House with Special Emphasis on Escherichia coli O157:H7, Ethiopia. J Veterinar Sci Technol 4: 132. doi:10.4172/21577579.1000132

Copyright: $\odot 2013$ Taye M, et al. This is an open-access article distributed unde the terms of the Creative Commons Attribution License, which permits unrestricted use, distribution, and reproduction in any medium, provided the original author and source are credited. 
Citation: Taye M, Berhanu T, Berhanu Y, Tamiru F, Terefe D (2013) Study on Carcass Contaminating Escherichia coli in Apparently Healthy Slaughtered Cattle in Haramaya University Slaughter House with Special Emphasis on Escherichia coli O157:H7, Ethiopia. J Veterinar Sci Technol 4: 132. doi:10.4172/2157-7579.1000132

Page 2 of 3

by Quinn et al. [9] and sterile gloves were used for each sampling to avoid cross contamination.

All collected swab samples were placed in the universal bottle containing buffered peptone water and transported in an ice box with ice packs to Veterinary Microbiology laboratory of Haramaya University and incubated at $37^{\circ} \mathrm{C}$ for 24 hours for enrichment. All preenriched carcass swab samples were subsequently subcultured onto MacConkey agar for primary screening of E. coli and incubated at $37^{\circ} \mathrm{C}$ aerobically for 24 hours. Suspected colonies of E. coli (pinkish color appearance) were subcultured onto nutrient agar (non-selective media) and confirmed by Triple Sugar Iron (TSI) and IMViC tests. Then the bacterium that was confirmed as E. coli was subcultured onto Sorbitol MacConkey agar from nutrient agar and colorless colonies (nonsorbitol fermenter) were again subcultured onto nutrient agar and Latex E. coli $\mathrm{O} 157: \mathrm{H7}$ agglutination test was performed to determine strains.

In vitro antimicrobial susceptibility test was conducted on all confirmed E. coli and E. coli O157:H7 for six antimicrobial agents [Tetracycline (Te30 $\mu \mathrm{g})$, Kanamycin (K30 $\mu \mathrm{g})$, Spectinomycin $(\mathrm{SH} 100 \mu \mathrm{g})$, Ampicillin (AMP10 $\mu \mathrm{g})$, Amoxicillin (AML10 $\mu \mathrm{g})$ and Chloramphenicol $(\mathrm{C} 30 \mu \mathrm{g})]$ by using agar disc diffusion technique as described by NCCLS [10].

\section{Data management and analysis}

All collected data were entered into Microsoft Excel data sheet and

\begin{tabular}{|c|c|c|c|}
\hline \multirow[b]{2}{*}{ Risk factors } & \multirow{2}{*}{$\begin{array}{c}\text { Number of animals } \\
\text { examined }\end{array}$} & \multicolumn{2}{|c|}{ No. of isolates (Prevalence) } \\
\hline & & E. coli & $\begin{array}{l}\text { E. coli O157:H7 from } \\
\text { isolated } E \text {. coli }\end{array}$ \\
\hline \multicolumn{4}{|l|}{ Breed } \\
\hline Local & 109 & $32(29.35 \%)$ & 0 \\
\hline Cross & 4 & $3(75 \%)$ & $3(100 \%)$ \\
\hline$p$-value & & 0.73 & 0.73 \\
\hline$x^{2}$ & & 0.11 & 0.11 \\
\hline \multicolumn{4}{|l|}{ Age } \\
\hline $1-3$ years & 21 & $9(42.85 \%)$ & $2(22.2 \%)$ \\
\hline 4-6 years & 56 & $16(28.6 \%)$ & 0 \\
\hline$\geq 7$ years & 36 & $10(27.7 \%)$ & $1(10 \%)$ \\
\hline$p$-value & & 0.425 & 0.07 \\
\hline$x^{2}$ & & 1.71 & 5.28 \\
\hline \multicolumn{4}{|l|}{ Origin } \\
\hline Chalanko & 31 & $7(22.6 \%)$ & 0 \\
\hline Kulubi & 34 & $9(26.8 \%)$ & $2(22.2 \%)$ \\
\hline Water & 8 & $4(50 \%)$ & 0 \\
\hline Kersa & 34 & $12(35.3 \%)$ & $1(8.3 \%)$ \\
\hline Haramaya & 6 & $3(50 \%)$ & 0 \\
\hline$p$-value & & 0.404 & 0.644 \\
\hline$x^{2}$ & & 4.011 & 2.56 \\
\hline Total & 113 & $35(30.97 \%)$ & $3(8.57 \%)$ \\
\hline
\end{tabular}

Table 1: Prevalence of carcass contamination with E. coli and E. coli O157:H7 and associated risk factors. statistical analysis was done by SPSS Version 17 statistical software. The variations between different factors were analyzed using chi-square $\left(\chi^{2}\right)$ test. A p-value $<0.05$ was considered to determine statistical significance using $95 \%$ confidence interval.

\section{Results}

The overall prevalence of carcass contamination with $E$. coli was $35(30.97 \%)$ (Table 1) and that of E. coli O157:H7 was 3 (2.65\%). The difference in prevalence of carcass contamination with $E$. coli and $E$. coli $\mathrm{O} 157: \mathrm{H} 7$ between the two breeds, among the three age groups and origin of animals was not statistically significant $(\mathrm{p}>0.05)$.

In vitro antimicrobial susceptibility test was conducted on all isolates. Out of the isolated E. coli, six were $100 \%$ susceptible to Tetracycline (Te30 $\mu \mathrm{g})$, Chloroamphenicol (C30 $\mu \mathrm{g})$, Kanamycin (K30 $\mu \mathrm{g})$, Spectinomycin $(\mathrm{SH} 100 \mu \mathrm{g})$, Ampicillin (AMP10 $\mu \mathrm{g})$ and Amoxicillin $(\mathrm{AML} 10 \mu \mathrm{g})$. Multidrug resistance (MDR) was also observed both in $E$. coli and E. coli O157:H7 to different drug disks (Table 2).

\section{Discussion}

Estimates of the prevalence of verotoxin-producing E. coli among populations of cattle vary considerably [11]. The overall prevalence of carcass contamination with $E$. coli species of the present study in the slaughtered animals was $30.97 \%(n=113)$ which is higher than $4.4 \%$ $(\mathrm{n}=885)$ prevalence reported in Kenya [12]. This might be due to lack of strict hygienic measures taken in Haramaya University slaughter house.

Cattle have been implicated as the principal reservoir of E. coli O157:H7 [13]. Many studies determined the prevalence of E. coli $\mathrm{O} 157: \mathrm{H} 7$ on cattle carcasses which were from $0.0 \%$ to $27.8 \%[13,14,15]$. The prevalence of E. coli O157:H7 (2.65\%) isolated from carcass in this study was in close agreement with the reported prevalence of $2.9 \%$ and $3.2 \%$ in the United Kingdom [16, 17], respectively. $2 \%$ in Canada [18] and five isolates $(2.8 \%)$ out of 180 meat and meat products examined in South Africa [19]. The lower carcass contamination might be due to low fecal prevalence of E. coli $\mathrm{O} 157: \mathrm{H} 7$ in these animals and operational activities in the slaughter house, which results in relatively low risk of contamination and cross contamination [5]. The exact contamination rate may be higher than the stated one due to the low isolation rate of culture methods compared to immunological and molecular methods [20].

In comparison to the present study, a higher prevalence of E. coli O157:H7 were reported from different countries; 8\% [5] and 8.1\% [6] in Ethiopia, 9\% in India [21] and 6\% in Turkey [22]. A lower prevalence of E. coli O157:H7 were also reported from America (0.8\%) [23], Kenya $(0.2 \%)$ [12] and New York (1.3\%) [24]. The overall variations in the prevalence of $E$. coli O157:H7 might be due to different sampling techniques, laboratory methodologies, areas, time and hygienic conditions used.

The difference between age groups, breed and origin of animals were not statistically significant $(\mathrm{P}>0.05)$. This disagrees with work

\begin{tabular}{|lcccc|}
\hline Antimicrobials tested & \multicolumn{2}{c}{ Susceptible } & \multicolumn{2}{c|}{ Intermidiate } \\
& E.coli & E.coli $0157: \mathrm{H} 7$ & E.coli & E.coli O157:H7 \\
\hline Te(30 $\mu \mathrm{g})$ & $51.4 \%$ & $66.67 \%$ & 0 & 0 \\
$\mathrm{C}(30 \mu \mathrm{g})$ & $74.3 \%$ & $100 \%$ & $2.86 \%$ & 0 \\
$\mathrm{~K}(30 \mu \mathrm{g})$ & $85.5 \%$ & $100 \%$ & $2.86 \%$ & 0 \\
$\mathrm{SH}(100 \mu \mathrm{g})$ & $85.7 \%$ & $100 \%$ & $8.57 \%$ & 0 \\
$\mathrm{AMP}(10 \mu \mathrm{g})$ & $28.6 \%$ & 0 & $5.7 \%$ & 0 \\
AML $(10 \mu \mathrm{g})$ & $31.4 \%$ & 0 & 0 & 0 \\
\hline
\end{tabular}

Table 2: Antimicrobial susceptibility profile of E.coli and E. coli $\mathrm{O} 157: \mathrm{H} 7$ isolates 
Citation: Taye M, Berhanu T, Berhanu Y, Tamiru F, Terefe D (2013) Study on Carcass Contaminating Escherichia coli in Apparently Healthy Slaughtered Cattle in Haramaya University Slaughter House with Special Emphasis on Escherichia coli O157:H7, Ethiopia. J Veterinar Sci Technol 4: 132. doi:10.4172/2157-7579.1000132

of Luga et al. [25] in which the seroprevalence of E. coli O157:H7 in cattle is significantly associated with sex, diarrhea status and age. The variation between these studies may be due to climatic variation which plays important role [26].

There was variation in antimicrobial susceptibility of E. coli in the present study. Similarly, tests conducted on stool samples collected from diarrheic patients in Korem, Ethiopia showed that $53 \%$ of E. coli strains were found to be resistant to ampicillin, $47 \%$ to Chloramphenicol, and $67 \%$ to Tetracycline [27]. Although there is significant variation between this study and the present study, there were resistant nature of E. coli species to ampicillin and tetracycline so long years back.

All isolated strains in the present study were found susceptible to Kanamycin $(\mathrm{K} 30 \mu \mathrm{g})$, Chloramphenicol $(\mathrm{C} 30 \mu \mathrm{g})$ and spectinomycin $(\mathrm{SH} 100 \mu \mathrm{g})$ and $100 \%$ resistant to Ampicillin (AMP10 $\mu \mathrm{g}$ ) and Amoxicillin (AML10 $\mu \mathrm{g}$ ) and $33.33 \%$ resistant to Tetracycline (Te30 $\mu \mathrm{g}$ ). Similar findings were reported by other researchers [5,28]. Multidrug resistant was also detected in $66.67 \%$ of the strains. This agrees with results of many workers report [5].

\section{Conclusion and Recommendations}

The present result revealed prevalence of carcass contamination with E. coli and E. coli O157:H7 from apparently healthy slaughtered cattle in Haramaya University slaughter house. The obtained higher prevalence indicated poor hygienic practice in the house. Age group, breed and origin of animals as potential predisposing factors were found to be not significantly associated with the occurrence of E. coli contamination. The isolated bacteria showed variety of susceptibility pattern against different antimicrobials used for in vitro test. Therefore, the following recommendations were forwarded:

1. Proper and strict hygiene is very important for equipments and personnel working in the house.

2. Creating public awareness about the bacteria and thorough cooking of products from the slaughter house is essential to reduce consumers' infection rate.

\section{Acknowledgments}

The authors are very grateful to staffs of Haramaya University College of Veterinary Medicine and University of Gondar Faculty of Veterinary Medicine for their kind cooperation during the study period.

\section{References}

1. Songer JG, Post KW (2005) Veterinary Microbiology: Bacterial and Funga Agents of Animal Diseases. Elsevier Health, New York, USA.

2. Callaway TR, Carr MA, Edrington TS, Anderson RC, Nisbet DJ (2009) Diet Escherichia coli 0157:H7, and cattle: a review after 10 years. Curr Issues Mol Biol 11: 67-79

3. Olatoye IO (2010) The Incidence and Antibiotic Susceptibility of Escherichia coli 0157:H7 from Beef in Ibadan, Nigeria. J Food Ptotect 9: 1196-1199.

4. OIE (2008) Verotoxigenic Escherichia coli. Terrestrial manual.

5. Hiko A, Asrat D, Zewde G (2008) Occurrence of Escherichia coli O157:H7 in retail raw meat products in Ethiopia. J Infect Dev Ctries 2: 389-393.

6. Mersha G, Asrat D, Zewde BM, Kyule M (2009) Occurrence of Escherichia coli O157:H7 in faeces, skin and carcasses from sheep and goats in Ethiopia. Let Appl Microbiol 50: 71-76.

7. Asrat GT, Berhan T, Solomon M (2008) Inclusion of Different Proportions of Poultry Litter in the Rations of Yearling Hararghe Highland goats. Livestock Research for Rural Development 20: 48.

8. DeLahunta A, Habel RE (1986) Applied Veterinary Anatomy. WB Saunders Company, Philadelphia, USA.
9. Quinn PJ, Markey BK, Carter ME, Donnelly WJ, Leonard FC (1994) Veterinary Microbiology and Microbial Disease. Blackwell Publishing, London.

10. National Committee for Clinical Laboratory Standard (1997) Performance Standard for Antimicrobial Disk Standard Susceptibility Test. Lippincott and Williams Wilkon, USA

11. Onyango AO, Kenya EU, Mbithi JJ, Ng'ayo MO (2009) Pathogenic Escherichia coli and food handlers in luxury hotels in Nairobi, Kenya. Travel Med Infect Dis 7: 359-366.

12. Chapman PA, Siddons CA, Cerdan Malo AT, Harkin MA (2000) A one year study of Escherichia coli 0157 in raw beef and lamb products. Epidemiol Infect 124 207-213.

13. Chapman PA, Cerdán Malo AT, Ellin M, Ashton R, Harkin (2001) Escherichia coli 0157 in cattle and sheep at slaughter, on beef and lamb carcasses and in raw beef and lamb products in South Yorkshire, UK. Int J Food Microbiol 64 139-150.

14. Doyle MP, Schoeni JL (1987) Isolation of Escherichia coli O157:H7 from retail fresh meats and poultry. Appl Environ Microbiol 53: 2394-2396.

15. Abong'o BO, Momba MN (2009) Prevalence and characterization of Escherichia coli $\mathrm{O} 157: \mathrm{H} 7$ isolates from meat and meat products sold in Amathole District Eastern Cape Province of South Africa. Food Microbiol 26: 173-176.

16. De Boer E, Heuvelink AE (2000) Methods for the detection and isolation of Shiga toxin-producing Escherichia coli. Symp Ser Soc Appl Microbiol : 133S-143S.

17. Dutta S, Deb A, Chattopadhyay UK, Tsukamoto T (2000) Isolation of Shiga toxin-producing Escherichia coli including $\mathrm{O} 157: \mathrm{H} 7$ strains from dairy cattle and beef samples marketed in Calcutta, India. J Med Microbiol 49: 765-767.

18. Baran F, Gulmez M (2010) The Occurrence of Escherichia coli O157:H7 in the ground beef and chicken drumsticks. Internet J Food Safety 2: 13-15.

19. McCluskey BJ, Rice DH, Hancock DD, Hovde CJ, Besser TE, et al. (1999) Prevalence of Escherichia coli 0157 and Other Shiga-Toxin-Producing Escherichia coli in Lambs at Slaughter. J Vet Diagn Invest 11: 563-565.

20. Goveris A, Angelidis AS, Katsoulis K, Pournaras S (2011) Occurrence, Virulence Genes and Antimicrobial Resistance of Escherichia coli 0157 in Bovine Caprine, Ovine and Porcine Carcasses in Greece. J Food Saf 31: 242-249.

21. Luga I, Akombo PM, Kwaga JKP, Umoh VJ, Ajogi I (2007) Seroprevalence of Faecal Shedding of E. coli O157:H7 from Exotic Dairy Cattle in North-Western Nigeria. Nigerian Veterinary Journal 28: 6-11.

22. Trček HK (2011) Impact verotoxigenic E. coli O157:H7 in animals on the health of the Slovenian population. Slov Vet Res 48: 83-92.

23. Desenclos JC, Zergabachew A, Desmoulins B, Chouteau L, Desve G, et al (1988) Clinical, microbiological and antibiotic susceptibility patterns of diarrhoea in Korem, Ethiopia.. J Trop Med Hyg 91: 296-301.

24. Schroeder CM, Zhao C, DebRoy C, Torcolini J, Zhao S, et al. (2002) Antimicrobial Resistance of Escherichia coli 0157 Isolated from Humans, Cattle, Swine, and Food. Appl Environ Microbiol 68: 576-581.

25. Reyes MS, Duran CT, Prado VJ (2004) Antimicrobial Susceptibility of Shiga Toxin Producing Escherichia coli (STET) Strains Isolated from Human Infections and Food. Rev Med Chil 132: 1211-1216.

26. Magwira CA, Gashe, BA, Collison EK (2005) Prevalence and antibiotic resistance profiles of Escherichia coli $\mathrm{O} 157: \mathrm{H} 7$ in beef products from retail outlets in Gaborone, Botswana. J food Prot 68: 403-406.

27. Meng J, Zhao S, Doyle MP, Joseph SW (1998) Antibiotic resistance of Escherichia coli 0157:H7 and 0157:NM isolated from animals, food, and humans.. J Food Prot 61: 1511-1514.

28. Mora A, Blanco JE, Blanco M, Alonso MP, Dhabi G, et al. (2005) Antimicrobia Resistance of Shiga Toxin (Verotoxin)-Producing Escherichia coli O157:H7 and Non-0157 Strains Isolated from Humans, Cattle, Sheep and Food in Spain. Res Microbiol 156: 793-806. 